\title{
PROBLEMS OF SCRUB CONTROL
}

\author{
W. F. LEONARD, Senior Scientific Officer, Department of \\ Agriculture, Christchurch.
}

This paper describes the distribution of the main scrub weeds in the South Island of New Zealand and offers comments on their control.

Climate, soils, and farm management practices set the pattern for the distribution and importance of scrub weeds. Wide variation in all three can be found in the South Island.

\section{Rainfall}

About and to the west of the main mountain range annual rainfall is high, exceeding 200 in. per annum in some places. Rainfall on the east coast is mainly between 24 and 30 in. but in Central Otago the figures fall below 15 in. per year. The foothills to the east of the main range, along with the northern and southern extremities of the island, experience between 30 and 50 in. of rain each year.

\section{Soils and Farm Management}

Scrub weeds are most competitive under low fertility. Although farmers can do little to alter the climate under which they farm, soil fertility and farm management can be manipulated in the interests of weed control.

\section{REGIONAL DISTRIBUTION AND IMPORTANCE}

\section{Gorse}

The scrub weed regarded as a problem in most South Island districts is gorse (Ulex europaeus). Information provided by the Department of Agriculture's South Island farm advisory staff revealed that in 14 out of 24 districts gorse was regarded as the most serious, or potentially serious, scrub weed. This doesn't mean, of course, that more than half the South Island is infested by gorse; it simply means that on land where the intensity of farming allows scrub weeds to grow, gorse is a major problem in all regions except the Mackenzie Country, Central Otago, and portion of Southland.

Gorse is versatile in the range of rainfall conditions it will tolerate, but is most troublesome in the medium to high rainfall regions. It is found, therefore, in varying amounts from one end of the South Island to the other. 


\section{Sweet Brier}

In seven districts sweet brier was considered the most serious weed, and it's not surprising that these included the drier and higher farming land of the South Island. Sweet brier may be found in many places, but is most aggressive where a dense ground cover can't be maintained. It is in areas of low rainfall and high altitude that these conditions are most likely to occur.

Dense infestations of sweet brier not only occupy grazing land but interfere with accessibility and are a constant hazard to sheep. Its seed has already been widely dispersed in areas where conditions are suitable for its spread.

\section{Manuka}

In three southern districts the native manuka (Leptospermum scoparium) was regarded as the most serious scrub weed. The widespread distribution of manuka is indicated by its being mentioned as a weed in 16 of the 24 districts. Control by the "manuka blight", however, is bringing about a decline in the importance of manuka as a weed.

\section{Broom}

While not regarded as the most serious weed in any one district, common broom (Cytisus scoparius) was considered a serious weed in nine districts and of some importance in 16. This plant, which is often associated with gorse, is spreading from waste areas such as riverbeds and roadsides. It is likely to claim more attention as a weed in future than it has in the past.

\section{Bracken Fern}

If we consider bracken fern (Pteridium esculentum) a scrub weed, it is undoubtedly the most widespread of all. But the presence of fern is not viewed with the alarm attached to weeds such as gorse and sweet brier. The reason is that fern is not an increasing problem, and is generally recognised as a weed of lowfertility land which is controlled as land improvement proceeds.

\section{Matagouri}

The native species matagouri (Discaria toumatou) is a weed of tussock lands which has increased in recent years. Its increase has been due in part to a reduction in the practice of burning tussock grassland, while response to fertiliser application has increased the vigour of matagouri plants already present. When growing in dense communities this thorny plant interferes with the accessibility of grazing land and, of course, restricts the area available to stock. 


\section{Blackberry}

Although very widespread in regions of medium and high rainfall, blackberry (Rubus spp.) has lost its place as a weed of great importance. It is still a considerable nuisance, but known farming techniques are now adequate for its control.

\section{Tutu}

Several species of tutu are native to New Zealand. The ones commonly encountered at lower altitudes are the low-growing species (Coriuriu sarmentosa) and the tree tutu (C. arborea). In higher altitude areas small-leaved species of the same family are found.

The problem stems from the poisonous nature of the weed rather than its aggressiveness. Newly introduced stock are most commonly affected. Where land development is proceeding and gullies are tutu-infested an even more acute difficulty arises. Tutu responds to topdressing with phosphate, thereby becoming more prominent, and stock grazing on improved pasture are more likely to browse tutu, presumably to introduce variety into their diet.

Tutu will not compete with vigorous pasture species, but during improvement a difficult period can occur.

\section{Spanish Heath}

A weed of low-fertility soils, Spanish health (Erica spp.) is widespread in the Nelson and Marlborough provinces. Where land development is possible heath can be brought under control, but some of the soils it infests have particular fertility problems.

\section{Tauhinu}

The native shrub Cassinia leptophylla, known in the South Island as tauhinu, is common in Nelson and Marlborough. Though it occurs also in other parts of the South Island, it is in the northern region that tauhinu causes most concern.

It is not aggressive under high-fertility conditions, and land improvement eventually brings about its suppression.

\section{Barberry, Hawthorn, and Boxthorn}

Scveral of our scrub weeds were introduced as hedge plants. In barberry (Berberis vulgaris), hawthorn (Crataegus monogyma), and African boxthorn (Lycium ferocissimum) we have three which subsequently escaped and are already causing concern in some districts.

Although the total area infested by these species is not yet great, they are potentially serious weeds and should be controlled while still in a manageable state. 


\section{Flowering Currant, Gooseberry and Elderberry}

The ornamental shrub flowering currant (Ribes sanguineum) is spreading in some localities and could become a serious weed if left unchecked. Gooseberry (Ribes uva-crispa) and elderberry (Sambucus nigra) occur as potential weeds, mainly in Otago.

\section{Hakea}

More than 20 years ago species of hakea were reported to be spreading in North Auckland. Two species (Hakea saligna and H. salicifolia) are established in the northern portion of the South Island and could well become troublesome weeds.

\section{Spiderwort}

About bush fringes in Nelson and Westland Provinces, spiderwort or Himalayan honeysuckle (Leycesteria formosa) is quite common. However, it is not regarded as a weed of great importance.

\section{Fuchsia and Carmichaelia}

The native species Fuchsia excorticata is some problem in South Otago on land cleared from forest. Native broom (Carmichaelia sp.) is attracting attention in Central Otago as a possible weed.

\section{CONTROL ON ARABLE LAND}

Whatever the weed species involved, cultivation is easily the most popular form of control on arable land. On soils subject to wind or water erosion cultivation could well be avoided, but normally on land where topography permits it this is the means adopted for scrub weed control.

\section{Clearing Land}

The pattern of cultivation varies according to the nature of the weed. For plants with extensive aerial or underground parts, heavy machinery is generally used in the early stages of development.

The scrub is crushed down before burning or the entire plants are removed from the soil with a bulldozer blade or root rake and pushed up into windrows. These are later burnt-where the climate permits-or left to decay slowly, harbouring meantime weeds such as blackberry.

Rotary slashing machines and forage harvesters have also been used to remove aerial growth. This may be done to facilitate cultivation or as a preliminary to oversowing and topdressing. In the latter case, the combined effects of competition from sown pasture species and concentrated stock grazing are utilised to suppress regrowth of gorse. 


\section{Cultivation}

After clearing, giant discs or a swamp plough are used for the initial cultivation. A levelling device may then be dragged over the ground before it is cultivated with tandem discs, roller, and harrows.

The stage to which cultivation is taken before the first sowing is made varies from place to place. Some farmers complete quite an elaborate programme of cultivation before sowing, whereas others sow a fodder crop such as turnips after a less intensive preparation.

Occasionally a "permanent" pasture mixture is sown without a preceding crop, but usually a fodder crop or short-term pasture comes first. Cultivation in preparation for sowing of the pasture then destroys scrub weed seedlings and any regrowth.

\section{Soil Fertility}

Scrub weeds thrive under intermediate and low fertility but to play their part the pasture species which we sow demand fairly high fertility. Most New Zealand soils are deficient in phosphate and some require other plant nutrients if sown pastures and crops are to thrive.

If scrub weeds are to be replaced with a useful ground cover, therefore, any deficiencies in soil fertility must be corrected. Clearing, cultivation, and sowing without taking soil fertility into account is a very poor investment.

\section{Costs}

The cost of clearing and cultivation will depend on the nature of the problem. In many districts clearing costs between $£ 15$ and $£ 20$ per acre and subsequent cultivation from $£ 5$ to $£ 7$ per acre. By the time a fodder crop has been sown the cost will probably have reached between $£ 20$ and $£ 30$ per acre.

To re-cultivate and provide seed and fertiliser for sowing to pasture will add about a further $£$ IO per acre.

\section{CONTROL ON NON-ARABLE LAND}

\section{Gorse}

Scattered gorse plants may be killed by various means, but control of dense gorse on non-arable land requires thorough planning. The farmer contemplating gorse control must realise that vigorous pasture competition coupled with controlled grazing is the key to success. 
The means by which existing gorse cover is removed may vary. If, by spelling the land to accumulate undergrowth, a uniformly hot fire can be produced, aerial spraying is unnecessary. Often, however, climatic conditions don't favour a satisfactory burn and aerial spraying may be used to achieve it.

After the burn, oversowing and topdressing are done according to the requirements of soil and climate. Concentrated, but controlled, stocking, made possible by adequate' fencing, then becomes the important factor in suppressing seedling and regrowth gorse.

Any regrowth gorse which survives can then be spot sprayed from the ground the next summer. The emulsifiable ester of 2,4,5-T applied to give complete coverage will kill gorse, but to expect to kill it out by aerial spraying alone-as many farmers seem to do-is over-optimistic.

Biological control operates on gorse in the form of the gorse seed weevil Apion ulicis (1). The fact that gorse flowers in winter, when the weevil is not active, limits the degree of control by the insect. It does, however, reduce the amount of viable seed produced.

\section{Sweet Brier}

No satisfactory chemical means of killing sweet brier has yet been found. A number of herbicides when applied from the ground to individual bushes will kill them, but such treatments are costly and not really applicable to large infestations.

The most reliable method used to date is the basal application of 2,4,5-T in diesel oil. Coverage spraying, owing to the lack of translocation of $2,4,5-\mathrm{T}$, is unsatisfactory so that aerial spraying of sweet brier with $2,4,5-\mathrm{T}$ can be a partial control only. A new material 2,3,6-TBA is being tested as a foliar spray and, if successful, could be used for aerial application.

Like most scrub weeds, however, sweet brier is susceptible to competition in the seedling stage, Meantime, therefore, infestations on arable land should be removed, scattered bushes on non-arable land destroyed wherever possible, and improved ground cover fostered on threatened land. The dry climate and high altitude under which brier is thriving make it difficult to provide a sufficiently competitive ground cover, but this should not discourage a farmer from carrying out pasture improvement where he can.

As with gorse, a suitable herbicide could become a tool for use in large scale control work, but is unlikely to be the solution.

\section{Manuka}

Until the control of manuka by manuka blight (the mealy bug Eriococcus orariensis) began to attract widespread attention about 16 years ago $(2,3)$, manuka control on non-arable land was 
restricted to hand cutting. The "blight" has now spread, by artificial and natural means, to practically all parts of the South Island (as well as to the North Island) and has caused manuka to diminish greatly in importance as a weed.

In Australia the insect is attacked by parasites, but for several years in New Zealand no parasite appeared to affect it and the blight was very active.

Fears of wholesale soil erosion after the death of large areas of manuka were not realised. Plants died slowly and were replaced by volunteer vegetation or sown pasture species. Where no useful species were introduced to succeed the manuka, other weeds, such as blackberry and gorse, have become established in many places.

The insect itself is now parasitised in this country by a fungus which restricts the incidence of the blight and has produced a balanced association of host and parasite.

B room

Broom will not invade a vigorous pasture, but it spreads over land where a dense ground cover is difficult to maintain. It is susceptible at the mature stage to $2,4,5-\mathrm{T}$. Some farmers and contractors find broom difficult to kill, perhaps because it is not easy to cover completely when spraying. Incomplete coverage when using 2,4,5-T leads to very patchy results.

\section{Bracken Fern}

Although resistant to the commonly used herbicides, bracken fern shows some susceptibility to 4-CPA. It grows, however, on low fertility soils and the basis of fern control must be land improvement.

Details of how the accepted technique of burning, oversowing, and topdressing followed by controlled grazing is being applied on a farm in Nelson Province, are contained in another paper of this session (4).

\section{M atagouri}

This weed does not invade improved pasture, but plants 'already present respond to phosphatic topdressing. In the past matagouri was controlled by periodic burning. A reduction in burning and an increase in topdressing have caused the plant to increase in importance as a weed.

Pasture improvement will protect land against establishment of new plants, but a herbicide may be required to control existing bushes on non-arable land.

In the small amount of research work done with herbicides matagouri has shown some susceptibility to 2,4,5-T and 2,4,5-TP. Further work, however, is required. 


\section{Blackberry}

With widespread land improvement our attitude to blackberry has changed. Instead of being regarded as a major weed of farm land it is now looked on mainly as a weed of unproductive land.

Blackberry can be controlled by spraying with the emulsifiable ester of 2,4,5-T when in the full leaf stage. Unless pasture improvement and concentrated stocking follow, repeat applications to regrowth will probably be necessary. A recently developed herbicide, 2,3,6-TBA, gives promise of producing a kill from a single application.

\section{Tutu}

The presence of tutu can be a special problem in land development. Although susceptible to competition from vigorous pasture growth, tutu persists for a time during the improvement phase. Land being developed by cultivation is frequently dissected by tutu-infested gullies. The concentrated grazing needed to control improved pasture then increases the risk of stock poisoning from consumption of tutu.

Heavy stocking necessary in a fern-control programme is difficult to implement where stock have access to tutu.

Thus, although pasture improvement should be the long-term approach to tutu control, spraying may be needed during the development stage. The emulsifiable ester of 2,4,5-T applied in summer will control it, though repeat applications will probably be required for a kill.

As sprayed plants are attractive to stock, they should be denied access to them for at least a week after spraying.

\section{Spanish Heath}

The best insurance against Spanish heath is improvement of soil fertility. It infests soils in the Marlborough and Nelson Provinces where phosphate and molybdenum are known to be deficient. Although considerable investigational work has been done on these soils, evidence suggests that their fertility problems are not yet fully understood.

Where heath is so dense that it would interfere with the establishment of sown pasture species spraying before oversowing the topdressing could be warranted. The most suitable material is the 2,4-D ester oil concentrate, which should be applied in diesel oil during summer.

\section{Tauhinu}

This weed is resistant to the commonly used herbicides. Hand clearing has been the only method of control used on non-arable land, and pasture improvement remains the most satisfactory form of control. 


\section{Barberry, Hawthorn, Boxthorn}

All three species are resistant to coverage spraying with the emulsifiable ester of 2,4,5-T. Although scattered bushes are killed by materials such as the substituted ureas and triazines applied at soil sterilisation rates, the most reliable treatment is with 2,4,5-T jil concentrate and diesel oil.

Plants of suitable size and accessibility are best cut off close to the ground and the mixture applied to the freshly cut stumps. Other plants may be sprayed about the base.

\section{Flowering Currant, Gooseberry, Hakea, and Elderberry}

A very limited amount of research work has been done so far on these potentially dangerous weeds.

Flowering currant has proved difficult to kill with chemicals and more research work on its control is required. Little is known about the control of gooseberry and hakea on non-arable land. Elderberry, however, is likely to be controlled by the treatment suggested for barberry, hawthorn, and boxthorn.

\section{Spiderwort, Fuchsia, and Carmichaelia}

Spiderwort and fuchsia are controlled by land improvement, the course of which can be aided by spraying with 2,4,5-T if required. Little is known yet about the control of carmichaelia.

\section{Control by Forest Trees}

Forest trees are widely used for suppression of scrub weeds. This form of control is particularly well suited to farms with rugged patches of land where any other type of production would be difficult to achieve.

Trees suffering from competition in gorse-infested sites are frequently oversprayed with 2,4,5-T to check the gorse and allow the trees to assume dominance.

\section{APPROACH TO WEED CONTROL}

Most scrub-weed control on arable land is undertaken primarily as a land development measure. On non-arable land, however, the effort is generally made with weed control in mind. As the development- of non-arable land progresses and the value of pasture improvement in weed control is more fully realised scrub weed control will become incidental to development on this type of land too.

Biological control of weeds should appeal to all except the marketers of weed-killing chemicals. However desirable this form of control may be, there are problems which restrict the extent 
to which it can be employed. Many weeds are related botanically to cultivated plants and to secure an effective parasite with a taste specifically for the weed species is not often possible.

Two well known parasites of scrub weeds in New Zealand are the insect causing manuka blight and the gorse seed weevil. We look hopefully to the entomologists to provide a biological controlling agent for sweet brier. The Entomology Division of D.S.I .R. are in fact looking with renewed interest at the whole field of biological control of weeds and insect pests.

Failure to regard aerial spraying as only one step in the process of gorse control has led to very disappointing results. Control on much of the 2,500 acres sprayed in the South Island last year will, therefore, be only temporary.

The uncertain economic outlook is causing many farmers to consider carefully before embarking on costly land-development work. The effect on scrub-weed control is offset to some extent by more intensive activity of local bodies in administering the Noxious Weeds Act.

Most private land development is financed from income, but many farmers resort to loan money for this work. Despite lower returns for farm products farming costs have not fallen, and the need to gain maximum return on money invested is greater today than for many years. This is true particularly of scrub-weed control, where money can be so easily expended for little or no return.

\section{CONCLUSIONS}

The main point to realise about scrub weeds is that they are a problem of low-fertility land. This points the way to their control. Spraying alone is unlikely to give long-term control; nor will it provide the additional production needed to pay for weed control. However, used in conjunction with soil-fertility improvement, herbicides can be a useful aid to scrub-weed control.

Small areas of potentially dangerous weeds should be destroyed without delay. There are other ways of clearing weeds than to wait until scientists produce and test a new chemical. Even now, if all the sweet brier bushes on arable land were removed, a major step forward would have been taken.

When faced with a difficult weed problem we are tempted to wait in the belief that sooner or later a chemical will be produced to control it. This is a dangerous attitude. A much safer approach would be to begin at once to make use of the facilities at hand. 


\section{References}

1. D. Miller, Control of Gorse by Seed Weevil, N.Z. Journal of Agriculture, Vol. 75, page 341 (1947).

2. T. G. Sewell, Manuka Blight Survey, N.Z. Journal of Agriculture, Vol. 79, page 101 (1949).

3. J. M. Hoy, Control of Manuka by Blight, N.Z. Journal of Agriculture, Vol. 79, page 321 (1949).

4. R. Inch, An Experiment on Control of Fern at Tutaki, N.Z. Grassland Association Conference 1962.

\section{Acknowledgements}

Help in the preparation of this paper from staff of the Farm Advisory Division, Department of Agriculture, the Botany and Entomology Divisions, D.S.T.R., and from spraying contractors is acknowledged with thanks. 